\title{
IMAGES OF WORLD: FROM THE IMAGES-TRACE TO THE ELECTRO-NUMERICAL SPACE
}

\author{
IMAGENS DO MUNDO: DAS IMAGENS-VESTÍGIO \\ AO ESPAÇO ELETRONUMÉRICO
}

\author{
IMÁGENES DEL MUNDO: DE LAS IMÁGENES-VESTIGIO \\ AL ESPACIO ELECTRONUMÉRICO
}

\section{Francesco Giarrusso}

\begin{abstract}
Although the cinematograph has appeared as an extension of the planimetric logic, thus updating the cartographic model of the Atlas, its emergence realized the dream-already potentially contained in the map's logic - of travelling the world in a straight line, with no interruptions, overcoming every restriction of time and space. Here, I examine the cinema's two-sided nature, its status of frontier between the spatial conception of the geometric-Euclidean system and the implementation of the spherical logic of the Globe; i.e. the evolution from the cinema's cartographic tendency to the electro-numerical image's creation and proliferation. Through this electro-numerical image, also due to the progressive colonization of the atmosphere, the Earth is no longer envisaged as flat, acquiring the shape of a network of lines and intersections. The planimetric logic underlying the image-trace no longer leads the world. Globalization denies the Euclidean geometry. Ubiquity and instantaneousness, implemented by the speed with which the electro-numerical image travels, cause the reality's progressive despatialization. That is the reason why the electro-numerical image no longer represents "the world becoming image" but "the imagination becoming world", unavoidably generating a new experiential horizon.
\end{abstract}

KEYWORDS: History of technology. Cinema. Cartography. Globalization.

\section{RESUMO}

Embora o cinematógrafo tenha surgido como prolongamento da lógica planimétrica, atualizando desta forma o modelo cartográfico do Atlas, o seu aparecimento veio concretizar o sonho - já contido em potência na lógica do mapa - de percorrer o mundo em linha reta, sem interrupções, suplantando qualquer restrição espáciotemporal. Trata-se de examinar a natureza bifronte do cinema, o seu estatuto de fronteira entre a conceção espacial própria do modelo de matriz geométrico-euclidiana e a implementação da lógica do globo, isto é, a passagem da tendência cartográfica do cinema à criação e proliferação da imagem eletronumérica através da qual, graças também à progressiva colonização da atmosfera, a Terra deixa de ser pensada como plana para adquirir a forma de uma rede de interseções e linhas. A lógica planimétrica, subjacente à imagem-vestígio, deixa de orientar o mundo. A globalização nega a geometria euclidiana, e a ubiquidade e instantaneidade, implementadas pela velocidade com que circula a imagem eletronumérica, causam a progressiva desespacialização da realidade, razão pela qual a imagem eletronumérica já não representa "o mundo que se faz imagem" mas "o imaginário que se torna mundo", gerando inevitavelmente um novo horizonte experiencial.

PALAVRAS-CHAVE: História da tecnologia. Cinema. Cartografia. Globalização.

\section{RESUMEN}

Aunque el cinematógrafo haya surgido como prolongación de la lógica planimétrica, actualizando de esta forma el modelo cartográfico del Atlas, su aparición cumplió el sueño - ya contenido en potencia en la lógica del mapa - de recorrer el mundo en línea recta, sin interrupciones, superando cualquier restricción espacio-temporal. Se trata de examinar la naturaleza bifronte del cine, su calidad de frontera entre la concepción especial propia del modelo de matriz geométrica-euclidiana y la implementación de la lógica del globo, es decir, la transición de la tendencia cartográfica del cine a la creación y proliferación de la imagen electronumérica a través de la cual, gracias también 
a la progresiva colonización de la atmósfera, la Tierra deja de ser pensada como plana para adquirir la forma de una red de intersecciones y líneas. La lógica planimétrica, subyacente a la imagen-vestigio, deja de orientar el mundo. La globalización niega la geometría euclidiana, y la ubicuidad e instantaneidad, implementadas por la velocidad con la que circula la imagen electronumérica, causan la progresiva desespacialización de la realidad, razón por la cual la imagen electronumérica ya no representa "el mundo que se hace imagen" si no "el imaginario que se vuelve mundo" generando inevitablemente un nuevo horizonte experiencial.

PALABRAS CLAVE: Historia de la tecnología. Cine. Cartografía. Globalización.

\section{CONQUERING THE EARTH}

L'Arrivée d'un train à La Ciotat (Auguste and Louis Lumière, 1896). The world is moving in our direction, pulled by the locomotive. The horror this causes does not come from the impression of reality or the fear of being run over by the steam engine, but rather from the dissolution of space whose images, which then began to spread everywhere, are today scattered like the plume of smoke that still hovers over La Ciotat train station.

Arrived at its destination, after centuries of journeys and explorations, mankind seems to fulfil its dream of travelling the world in a straight line, without any interruptions, being able to look into its most remote corners. In the blink of an eye, the Earth opens itself to the scopic voracity of mankind, whose gaze breaks with the usual perceptual horizon and begins to comprehend ${ }^{1}$ the Earth as a whole. There are no more secrets; the ecumene has been conquered and the image has taken over the world, replacing the latter with a far more attractive and efficient substitute.

The huge increase in all kinds of optical spectacles and devices, especially during the second half of the nineteenth century, proclaims once and for all the supremacy of the eye as the organ responsible for observing reality. The image becomes the absolute protagonist of all processes dedicated to the exploration and knowledge of the world, whose wonders, already widely accessible, entertain crowds in big cities. Throughout the nineteenth century, visual faculties are optimised and their sphere of action widened. This, together with technological developments in image reproduction devices, enabled human beings to explore regions and spaces that until very recently had been out of their reach. It is enough to think about the fast consolidation of photography, the research carried out by Eadweard J. Muybridge and Etienne-Jules Marey on the break up and observation of animal and human locomotion, or the spread of artificial light in cities, which literally brought new light to places that had hitherto remained plunged in the darkness of the night. Furthermore, the development of means of transport like the train gave the human eye access to a sequence of landscapes at a speed that only a few years earlier would have been unthinkable.

Nature becomes spectacle and the train ride becomes the precursor of the cinematic experience. In fact, it is not just science that benefits from the achievements of optics; the

1 In the double sense of "to understand" and "to include or encompass". 
technological developments made in exploring the visible were also felt in the entertainment industry thanks to the success of moving panoramas. The huge landscapes painted on panoramas show "the city dweller's [...] attempts to bring the countryside into town" (BENJAMIN, 2003, p. 6). And while the affinity with the train ride seems to exhaust itself in a mere metaphor, the simulation staged by the Moving Pictures in the United States does no more than confirm the direct link between the view seen from a window in a train carriage and the perception of the cinematic image. Unlike the European panorama, its North American counterpart brought a deep change to the role of the spectator. The mobility of the observer, who used to move along the canvas, is now replaced by a series of successive images, as if perceived from a moving train. Motionless, the spectator of the Moving Pictures watches the painted landscape advance, anticipating the spectator condition characteristic of the cinematic device. It is surprising to see how cinema finds inspiration in the train, appropriating its physiognomy to create spaces where the cinematic experience takes place. The Hale's Tours, created by George Hale, prove this similarity. Projections happen in rooms similar to train carriages from whose windows spectators can see picturesque images of America from the beginning of the twentieth century, which had previously been captured from the rear of a moving train.

Cinema and the train are the last means of land transport, with which globalisation comes to an end (i.e. terrestrial globalisation, according to Peter Sloterdijk's theory) ${ }^{2}$. Both allowed an increasing number of individuals to travel long distances in the shortest time possible, proclaiming the triumph of modernity, technology's domination of the Earth reduced to a globe. From Columbus's first voyage to Marconi's first radio transmission, Western civilization has always tended to conquer, inventory and appropriate space. The colonization of territories and the conversion of souls: these were the intentions behind the mobilisation of men, the overcoming of distances, and the reduction of the ecumene, whose miniaturisation aimed at capturing the world in a mesh that could contain it, making it easier to travel and control. "Cinema goes everywhere" (Delluc quoted in CASETTI, 2005, p. 29). From the very start of their cinematic activity, the Lumière Brothers sent their operators to the four corners of the Earth so that they would record images of mankind and the world. These images would then be given to the Western bourgeoisie, whose interest for the exotic concealed its will for power and ethnocentric view. Cinema replaces and updates the already declining imperialist policy of nation states, crystallising their essence in the cinematic image, and it is under the aegis of Hollywood that the United States will exert their cultural and political influence worldwide ${ }^{3}$.

\footnotetext{
2 Peter Sloterdjik's tripartite concept of globalisation has been adopted, following his neomorphological hypothesis. Regarding the German philosopher's understanding of globalisation, see Im Weltinnenraum des Kapitals. Frankfurt: Suhrkamp, 2005, and the Spheres trilogy consisting of: Sphären I - Blasen, Mikrosphärologie. Frankfurt: Suhrkamp, 1998; Sphären II - Globen, Makrosphärologie. Frankfurt: Suhrkamp, 1999; and Sphären III - Schäume, Plurale Sphärologie. Frankfurt: Suhrkamp, 2004.

3 As early as 1919, Louis Delluc emphasised cinema's extraordinary persuasive power over the masses: "The screen is more effective on international masses than a political speech" (quoted in CASETTI, 2005, p. 29).
} 
The Lumière Brothers did not believe in the huge economic potential of their new device, showing little business acumen. Furthermore, their decision to abandon their cinematic work also shows to a certain extent the frailties of the analogical image and the impossibility of putting a universal image library together. Not that cinema lacked such a propensity. Ever since its advent, it has been celebrated for its ability 'to 'embrace' the world: it [cinema] is able to hold all the spheres of nature in its hands-the human, the animal, the mineral, the vegetable; and in taking possession of these realms it is also able to adopt their various points of view." (Delluc quoted in CASETTI, 2005, p. 29) It is precisely that all-encompassing feature, together with the apparent ubiquity it simulates when moving from one "view" to the next in nature, from one frame to the next in the filmic text, that triggers the world's de-spatialisation process, which is then carried out with the creation of the first electro-numerical image. Cinema foreshadows the end of the planisphere in favour of the satellite image.

Le voyage dans la Lune (Georges Méliès, 1902). The drawing on the blackboard reveals the journey that humanity will soon make. The mesh that covered the world is unravelled and widens out to the depths of the cosmos. Horizontality, which had characterised journeys by land and sea ever since the Discoveries, was now giving way to verticality, to technology's propelling impulse. Although his vehicle was also heavier than air, Méliès ventured beyond the skies of Gaspar F. Nadar, defeating gravity once and for all. Cinema is one of the most efficient and powerful means of transport of all times, the forerunner of space travel during the second half of the twentieth century. Its invention accelerated the contraction process of the Earth, previously an immense sphere, which was reduced to a mere dot in space. The optical instruments pointed at the sky reduce the distance separating the company of explorers from the surface of the moon. Eyesight is extended and distances overcome: only a few seconds separate preparing the trip from landing on the Moon and thanks to editing mankind's ubiquitous dream comes true.

But that was not it. Extending eyesight beyond the usual horizons showed the need, strongly felt at the time, to draw space and humans closer to things, with the aim of reaching their most inner nature. Thus cinema, though maintaining a certain magic halo, shared similarities and a purpose with other observation instruments: to pierce through matter in order to explore and admire its composition. The apparent objectivity of a mechanical type of recording also made the cinematic medium a technical laboratory instrument at the service of science and the study of phenomenal reality. Several were the strategies adopted for it to pierce through things, widening the visible spectrum of the human eye.

Despite the Moon's fictitious face recreated with Méliès's typical illusionist strategies, the visual and visionary power of the cinematic device was heralded by the ante litteram travelling shot with which the spectator subjectively followed the space capsule. 
Whether by re-producing ${ }^{4}$ reality or re-constructing a hypothetical world, cinema extends and reshapes on screen our scopic relationship with the world, at once revealing and renewing our position before it. As the capsule approaches lunar soil, it is possible to admire the protuberances of its surface and the soul of the Moon is unveiled from a closer point of view that is essential to frame it. The first close shot of the Moon's face reveals the intimate physiognomy of the moonscape, capturing Her Majesty expressing all her telluric force. But there is no landscape until it is acknowledged as such, since only territory can dispense with the presence of humans. And it is precisely the human being, the subject, "who knows everything else without being known by anyone" (Schopenhauer quoted in SLOTERDIJK, 2006, p. 132), who assigned the observed space the connotation of landscape, blinding this space in order to get to know it and appropriate it. Representation begins the moment the represented object is inert in its blind immobility. Finally, the Moon is at the mercy of the Earth's crew.

In truth, Méliès's man, far from seizing the Moon - an inhospitable, pitfall-laden satellite inhabited by bizarre creatures that occupy its depths-, conquers the entire Earth, admiring it from space while it rises in the sky. This external point of observation clearly explains the theoretical position assumed by modern science since its consolidation: only what Man keeps at a "distance", alienating himself "from his immediate earthly surroundings" (ARENDT, 1958, p. 251), can be analysed. This stepping back caused a dramatic reduction in the size of the Earth, while - even though this might at first seem strange-increasing its visibility. Such a contraction process, paradoxically stemming from mankind's desire to expand its cognitive horizons, confirms the premise that the object observed must be kept at a distance in order to be seen. Using its mind, mankind moves closer to this object in order to measure it and get to know it. Contained within the borders of an image, the Earth, once immeasurable, is now transmuted into a sphere whose points, perfectly identifiable in the mesh enveloping it, are reduced to mere straight lines that can be walked with the eye.

A la conquête du pôle (Georges Méliès, 1912). The whole world fits into a room. Reduced to a sphere, it listens to lively lectures given by several delegations from all over the world, eager to reach the last region on planet Earth yet to be explored: the North Pole. The "globenauts" get ready to begin their expedition. Cars, boats, airships, balloons and strange locomotion machines are suggested in an effort to make technology rule over nature, leaving the world with nothing else to hide. However, the Earth back then did not ensure adequate speed and the journey had to be completed as fast as possible, avoiding the irregularities scattered around its surface. Engineer Maboul-literally meaning "crackpot" in Frenchissues an invitation to take off and conquer the world. However, it certainly won't be his strange machine taking Man to the North Pole. This task will be assigned to cinema, the only

\footnotetext{
${ }^{4}$ As discussed further on, this spelling suggests the "double level" that forms reality and, consequently, the original instance, as explained by Jean-Claude Coquet's (2008) phenomenology/semiotics of instances. When applying this theory to the study of the status of images created by human beings, it could be stated that these are never a direct representation of the world but rather a re-presentation of it; images give shape to our experience of reality and project our perceptions of it.
} 
medium capable of projecting humanity into distant lands, making it a mass participant in this last expedition it is allowed to make. At this time the cinematic image had already taken over the entire world, travelling it at unprecedented speed and prefiguring the huge traffic jam that Delluc had sensed in the beginning of the 1920s when he defined cinema as an "expressive industry [...] heading toward the simultaneous perfection of art and traffic." (Delluc quoted in CASETTI, 2005, p. 29)

The countless parading vehicles, almost rivalling the constellations and comets to reach their destination, reflect the homogeneity of space because the peculiarities of places down here cannot be distinguished from high up in the skies. Traffic is heavy. The trajectories of air transport draw new maps made of invisible straight lines, new routes through which the image-commodity will move above our heads. The dematerialisation of the Earth's mesh thus begins. Charles Lindbergh will prove its inconsistency and air traffic, which will soon envelop the Earth, replaces the mesh that had sustained our beliefs during approximately five centuries. The world is no more than a sphere on which to exercise the right of ownership.

A smiling Engineer Maboul is well aware of this since he owns one. It is not the world that precedes maps but rather maps that precede the world, thus determining its ownership.

The two-dimensional image implies and legitimises ownership. Three-dimensionality is banned from representation so that the world, perceived as being flat, can be compressed and subjugated. The image triumphs over the body and only those who turn the sphere into a surface and the world into a picture have power over space. "Imperialism is applied planimetry" (SLOTERDIJK, 2006, p. 142) and cinema the most recent medium to put it into practice.

The tendency to inventory and conquer territory finds a legitimate ally in the nineteenth-century photochemical image. Take, for example, the pivotal role of photography in the real and imaginary unification of the United States (cf. DE VECCHI, 2000, p. 12), or the curiosity and strong desire for knowledge felt by the first spectators of the Lumière views, and not just for the obvious reasons linked to technological novelty.

However, cinema is not exhausted in its mere documentary role. Although on the one hand it met the typically positivist tendency for cataloguing, prolonging the cognitive interest in space (materialised, for example, in scientific drawing before the advent of the photochemical image), on the other hand it fostered an element of illusion by associating itself to devices such as dioramas and panoramas, whose spectacle nature actually exceeded the taxonomic intentions of the scientific method. In the beginning, the cinematic image combined the mechanical ability to grasp reality (with classifying purposes often linked to expeditions and the diffusion of the picturesque) with a clear fondness for fantasy and phantasmagoria, typical of the illusory character of the moving image, making nature a spectacle to be enjoyed from a distance, no longer in praesentia but in absentia. 
The photosensitive image originates from analogical contact or the digital conversion of light. It is a mark, an index, a distant shadow of an existence whose absence we admire. The object of photography or of the cinematic image is neither a person nor a thing, but rather the light that makes it possible to inscribe these bodies on the film. In fact, we do not experience the concrete presence of objects and people in images; on the contrary, we realise their absence is made of the light that extracted the world from the darkness of inexistence, making it tangible to human eyes. "We do not see things in images, but the visibility of things per se" (BERTETTO, 2008, p. 92), the shape the world gains in contact with light and the relationship it establishes with the perceiving subject. What remains on the film is thus a chromatic flow that reveals the deep appearance of things, the way our eyes perceive them through lighting, shadows, reflections and colour, that is to say, all aspects of the world that are not exactly real and only exist visually, like ghosts (cf. MERLEAU-PONTY, 1964a, p. 28). The phantasmic nature of filmic images is given away by their intangibility since film shapes the visibility of the incorporeal, not the matter of which the world is made. Images cannot be replaced by their referents because they each have a different nature. This is why the re-production of the visible is never a duplication of the object but rather a presentification of its absence.

The cinematic image re-presents the world on the basis of its immaterial features, reestablishing mankind's relationship with it. Phenomenal reality leaves the perceptual horizon of the spectator, now immersed in darkness, while the screen is invaded by a world in everything (or almost everything) similar to ours. Forced to immobility during film screenings, the new voyeur-voyageur prepares to go around the world without any restrictions, making the movie theatre "the stage for modernity's journeys" (BRUNO, 2006, p. 41). And it makes no difference whether the re-presented reality is real or fictional, because cinema restores us the world, giving it an apparent similarity to what it re-presents. In fact, the filmic image re-produces external reality, excluded from the spectator's view, in order to enhance mankind's experience of the world, suppressing its materiality to highlight its essential features and countless variants. In this sense, the cinematic device becomes the means through which human beings can become aware of the reciprocal relationship that connects them to the world and to each other. By helping us perceive others, images enable us to grasp and decipher human beings and our actions, as if we were facing a mirror. Cinema is a place of selfrevelation through which spectators become aware of their own subjectivity and of their bodies as objects. Following Merleau-Ponty, it could be stated that the specular surface of the screen reveals the enigma of the body which "sees itself seeing; [...] touches itself touching; [...] is visible and sensitive for itself. It is a self [...] by confusion, narcissism, inherence of the seeer in the seen, the toucher in the touched, the feeler in the felt - a self, then, that is caught up in things, having a front and a back" (MERLEAU-PONTY, 1964a, p. 18-19).

The spectators' perception on screen of someone else's experience in the world makes visible "that to which [they] will never be present" (MERLEAU-PONTY, 1964b, p. 114), materialising to their eyes the essence of that person's being-in-the-world. In short, cinema reveals the perceptual process through which human beings become aware of themselves, 
inasmuch as the visible presentifies the invisible to the see-er (cf. MERLEAU-PONTY, 1964b). "Man is a mirror for man" (MERLEAU-PONTY, 1964a, p. 34) in a reciprocal relationship through which the "seen body" and the "seeing body" meet and are reflected in the same space: the cinematic screen. This double vision takes place "because there is a reflexivity of the sensible" that cinema, as a mirror, "translates and reduplicates" (MERLEAU-PONTY, 1964a, p. 33). And all this is only possible because "the body is made of the same flesh as the world" (MERLEAU-PONTY, 1964b, p. 302) and "the flesh is a mirror phenomenon" (MERLEAU-PONTY, 1964b, p. 309), capable of unfolding body and things into interior and exterior (cf. MERLEAU-PONTY, 1964b).

However, interiority is not only understood as one of the "faces" or one of the "leaves" that form the human being and allow the world to meet things and things to meet the world (MERLEAU-PONTY, 1964b). Interiority also refers to humans' "soul" (MERLEAUPONTY, 1996), to what is invisible to them. "The filmed image, however, is neither entirely on the film, nor definitely on the screen, nor actually in the beams projected by the lantern" 5 (SCHEFER, 1980, p. 117); it settles within us, witnesses of its transition, guardians of its fleeting memory made of light and celluloid. Cinema dwells in the dark room of our interiority, animating wandering ghosts, sensations, feelings, passions and affections and turning them into actions, inscribing upon our invisible experience the traces of a world that has never been touched but that is indelibly projected into our memories. A world without matter, that slides in between the strata of memory, paradoxically increasing our knowledge of reality.

Viewing cinema makes us leave our bodies and touch the specular surface of the screen, where images of our inner history twinkle (or, at least, reflections of that world of light and shade so similar to ours), thus expanding our sphere of individual experience. Watching a sequence of images that disappear before their astonished eyes, spectators take hold of someone else's memory, wandering between the spaces of an emotional geography of which they note down the coordinates. Cinema prolongs phenomenal reality, widening its borders: it is the place of a "journey-stability" (BRUNO, 2006, p. 96) through which the spectator experiences "several (mental) spaces and time fragments in a single real space" (BRUNO, 2006, p. 177), being responsible for their existence. These are, therefore, imagetraces of a psycho-geographical itinerary that inscribes itself on the spectator-flâneur of the age of technological reproducibility.

The cinematic device updates human beings' exploring nature, their sensory-motor apparatus, and their will to appropriate nature in order to disclose its laws and control its forces. Instantaneity and ubiquity, brought by the gradual increase in the speed at which the new means of locomotion - among which the movie camera - move upon the surface of the Earth,

\footnotetext{
${ }^{5}$ The original text in French is "L'image filmée ... . n'est cependant ni tout à fait sur la pellicule, ni définitivement sur l'écran, ni réellement dans les rayons que projette la lanterne."
} 
allowed humanity to declare its supremacy over the planet. However, at the same time as it did so, it gradually lost sight of the planet and how it functions.

Ever since its advent, cinema confirms the victory of the cartographic logic and prefigures the end of the process that inventoried the Earth and changed its face into a single map. It empowers vision, now aided by the movie camera's mechanical analogon that overcame distances in the wink of an eye. Cinema travels the globe; it is "a place of "traffic" (Delluc quoted in CASETTI, 2005, p. 31) where the transit of images becomes more intense. And traffic, as is known, requires the establishment of a network of exchange and the suppression of any point of reference to guide us through the surface of the Earth, whose centre is now everywhere at the same time.

"The movie camera becomes a moving camera - a means of "transport"” (BRUNO, 2006 , p. 24). It is not by chance that its invention happens during a century that, from a technological point of view, witnessed the proliferation of spectacles and devices that materialised or simulated the experience of travelling, the physical or imaginary movement of bodies in space. From framing the image to the camera's movements ${ }^{6}$, cinema in its early days is laden with the culture of exploration and geographical representation, exhibiting a particularly close kinship with cartography. Even the plots of the first panoramic films, the recurrent central role played by travelling or the explicit intention to document film screenings reveal how figurative codes and the syntax of cinematic language descended from a complex genealogy spanning from the seventeenth century Dutch tradition of descriptive representation to the Romantic emphatic representation of landscapes. (cf. DE VECCHI, 2000).

Movie theatres became focal points where aesthetic-scientific trends and models of space representation converged, after having matured for centuries. Early cinema reflects the heterogeneous nature and phylogenetic process that had led to its advent. Owing to its ability to re-produce phenomenal reality, cinema first inherited the desire for taxonomy of scientific drawing and then the tendency to inventory, typical of the deictic language of photography. It descends from maps, seen as the conventional representation of space according to Euclidean geometric-topographical precepts, and from the urban and landscape veduta associated with picturesque journeys and panoramic views. Cinema sets space in motion, inspired by various figurative codes, combining an element of illusion brought by artistic representation with the objectifying photomechanical process. All in all, the grammar of the nascent cinematic language embodies the composite practice of spatiality just as it was put in practice, for example, by the veduta, whose peculiarity consists in combining multiple points of view within the same representation. The budding cinematic form of the veduta, conferred by the coexistence of irreconcilable perspective points (such as aerial and street views), flowers with

${ }^{6}$ Concerning camera movements in cinema's early days, Giuliana Bruno (2006, p. 20) writes: "When the camera is placed at the very front of a moving vehicle — in trains, most typically; in subway cars [...]; on streetcars [...] or on vehicles moving through the street, [...] - the camera becomes the vehicle: that is, it becomes, in a literal sense, a spectatorial means of transportation." 
the advent of cinema, enabling the succession of different frames and allowing the eye even more mobility within the image. Moreover, editing arises as an extension of the planimetric logic, a spectacular update of the modern cartographic model, not only because of its similarities with the atlas (both inventorying image-excerpts of the Earth, overlapping and linking together views/frames of the world reduced to fragments with different scales) but also because of its ability to show the places of the ecumene, allowing the spectator-traveller to re-traverse spaces and share the geographical emotions triggered by the re-presentation of physical/imaginary journeys.

From the point of view of the spectator's reception, the cinematic device also shows the influence of cartographic thinking, whose figurative model was derived from Alberti's perspective system. The two-dimensional representation of phenomenal reality; its reproduction to scale through projection; the privileged position of the spectator "placed at the "centre of the field of vision' [...] [from where] the image can be received as a whole" (CAPUCCI, 1993, p. 91); the keeping of distance between observer and observed by maintaining a static point of view that ensures the necessary space for the subject to fully comprehend the reality re-produced: all of these are features of which cinema will become the main supporter during modernity, features that it will use to explore and exploit space, which will gradually become a commodity. The cinematic perspective is a central one, in which the image is drawn by the "rectilinearity" of the light beam that travels the distance between the projector - an eye-lighthouse placed in the centre of the room - and the "screenmap" where the world gains shape. The purpose here is, therefore, to emphasise the similarities between the two devices - the cartographic and the cinematic-, namely their shared terminology and the way they both represent outside space. The way these images are experienced is dictated by laws of perspective through which the position of the hypothetical spectator always overlaps with the gaze of the author of the "discourse", i.e. of who, when framing the image, is already suggesting the very viewing angle to the observer.

\section{FROM THE SENSIBLE TO THE INTELLIGIBLE}

In this sense, together with the representation of space according to the canons of perspectiva artificialis, the cinematic image becomes a "frame", a "window" (Deleuze in DANEY, 1986, p. 11) giving access to the experience of those who, by looking at the world, show their personal view of things. Cinema provides distance, the necessary space for us to find our own selves, teaching us how to "tirelessly touch with my gaze the distance from me at which the other begins" (DANEY, 1994, p. 39). Cinema creates a common territory, "it is a supplementary country on the map" (DANEY, 1993, p. 140) where interaction takes place "between" points of view on the world, and the immaterial border between the two constituent forces of the cinematic image - the eye that looks at us and that we look at - gains shape. This is why we always recognise ourselves in others, because there is always someone behind the image-trace: "a man, an author and, ultimately, a father" (DANEY,1994, p. 82). This is Daney's definition of cinematic experience, on which he bases his concept of cinephilia. Cinema proves our existence as guarantors of the experience of others, while simultaneously 
enriching the experience of each one of us when we appropriate the gaze of someone else. The image of others reveals what we are; it becomes the space where we realise that we share a same horizon, that we live in a supplementary country with shifting borders: the country of cinema. Surprised by being able to live in multiple places at the same time, we spectators are confronted with a world that shows us other realities. In order to understand them, we must re-traverse filmic images to be able to move towards the subject from whom they originated and reconcile ourselves with him/her.

Such a shared experience, often compared to travelling by Serge Daney (1993), stems from the tradition of geographical accounts, both in literature and art, which aimed at describing the places visited by explorers and recording the feelings those places had triggered in them. To travel is to narrate, and only those who come from afar have something to tell (cf. BENJAMIN, 2002, p. 144). Cinema turns that narrative into spectacle and its consubstantiality with the travel culture is reflected in cinema's language and techniques. Cinema is about traversing, about places first perceived and then re-lived, places whose traces remain indelibly in the images: narrativised spaces to where multiple consciousnesses converge and within which these consciousnesses interact. These consciousnesses belong to the nomadic explorer and the sedentary spectator, both driven by an impulse that, although in different ways, encourages them to travel across the surface of the Earth and the surface of the screen in order to satisfy their desire for knowledge and their attraction for fantasy.

Concerning this deep intrinsic characteristic, Giuliana Bruno (2006, p. 101-102) confirms that the physical encounter between cinema and travelling took place precisely during the travel conferences of the end of the nineteenth century, when it was common to illustrate the expeditions made to far off places - first with the magic lantern and later with films. However, a new gaze, which could be described as touristic, begins to gain importance and replace the documentary-disseminating intentions of these conferences. Paradoxically, this happened exactly when the objectifying path travelled by the photomechanical image should have ensured some objectivity to the representation of landscapes. The gradual transformation and fusion of the antithetical functions that had since always characterised the documentary illustration-representation of space took place. Although the objectification of the image of the world still meets the cognitive demands to have a direct record of the world's places, thus ensuring greater scientificity to representation, the reduction of human intervention in capturing images of phenomenal reality encourages, on the contrary, the dissemination and increasingly faster consumption of those images, in which the aesthetic value prevails. It was as if, during the second half of the nineteenth century, the impulse for exploration had exhausted its cataloguing mission. The entire globe had in fact been mapped, making room for the emerging touristic spirit, whose curiosity could finally be satisfied as people and images began travelling with greater ease. And it was precisely early cinema that most contributed to assert the nascent civilization of the image-commodity, since it allowed to spread the touristic practice of the spatial image, turned into a consumer good. Furthermore, the cinema spectator and the tourist are both travel consumers, satisfying their own scopic bulimia with images of space. 
The speed at which cinemas grow in urban centres contributes to the many changes undergone by humanity during the end of the nineteenth century. Human beings' perceptual horizon is changed by the deep revolution in transport that, by speeding up travel, alters the physical and mental geographies of passengers. Modern means of locomotion and their predefined routes determine the coordinates of the space within which journeys to and fro originate, rendering the surface of the Earth increasingly homogeneous. In fact, the cinematic image contributes to gradually overcome distances and, as the Earth becomes smaller, spectators can admire its wonders within a single gaze, without having to verify in situ what they are seeing. The figure of the explorer, of the documenting traveller, begins to disappear and is overtaken by the individual of the last stage of globalisation: the tourist. Just like the cinema spectator, the tourist "pays money in exchange of experiences in far off theatres" (SLOTERDIJK, 2006, p. 50).

With the invention of new speeds, globalisation ${ }^{7}$ makes another evolutionary leap, raising several epistemological problems regarding the definition of space and time, and the configuration of the image model underlying the representation of the world, within the current virtualisation context. "Each new means of communication and transport [...] changes the system of concrete proximities, that is, is the pertinent space for human communities" (LÉVY, 1997, p. 12), generating new cartographies and experiential horizons. Moreover, there is a close link between the speed of progress in transport technology and in image technology (cf. VIRILIO, 2005, p. 30), both responsible for changing contemporary human beings' perception of phenomenal reality. While at the dawn of cinema and trains the geometric-Euclidean system was still valid for interpreting the world, with the technological and scientific developments of the twentieth and twenty-first centuries the planimetric representation of the world was definitely overcome by the rapid growth of air routes and the establishment of the IT networks. In fact, with the satellite colonization of the atmosphere, the Earth ceases to be thought of as being flat and gains the shape of a network of lines and intersections. The planimetric logic no longer guides the world. Globalisation denies geometry and space. Ubiquity and instantaneity, brought by the speed at which information-commodity circulates, result in the progressive de-spatialisation of reality, overcoming any distances between the points of the Globe.

The propelling impulse caused by the acceleration with which anthropisation brings an end to the colonisation of the planet is also determined by the technological development of audiovisual recording and transmission systems. The computerisation of the image and its dizzying speed of propagation change the way phenomenal reality is perceived. Furthermore, they change the role of human beings in the production and perception of the new electronumerical images. It can be stated, quoting Virilio (1989, p. 118), that "abandoning the vehicular speed of bodies for the far more impressive speed of light vectors" changes the

\footnotetext{
${ }^{7}$ According to Peter Sloterdijk (cf. 2006, p. 38-39), humanity has gone through three distinct stages of globalisation: the cosmic-Uranian, the terrestrial, and the electronic globalisation "associated with contemporary human beings and their successors".
} 
dimensions of space-time to the extent that the body loses its role as the fundamental referent of human action, as the centre and measure of the world. The expansion of space-put in action by digital technologies, whose information flow nourishes their growth - and the assertion of telepresence significantly reduce the sphere of action of the physiological body, incapable of dealing with the infinite, simultaneous, interconnected worlds. Moreover, the generative process of a certain type of electro-numerical images dispenses with the "perceptual/evaluative instance", understood as the "instance originating/producing" the image re-production of an event and the sensible experience previously triggered by that event. This is why electro-numerical images no longer have any trace, neither of mankind's carnal relationship with the world of physis nor, consequently, of the translation/projection of its "being in the world" onto the axes of logos (cf. COQUET, 2008) ${ }^{8}$.

These images, although also based on the principles of the perspective representation of space and simulating the functioning of human beings' visual apparatus, are synthetic figurations in which the representation of real or symbolic worlds is exclusively carried out with computational machines. This is why "the image is no longer the material trace of an encounter but a genetically codified being” (DANEY, 1993, p. 346). This does not imply that the distinctive feature of electro-numerical images lies solely in their ability to reproduce visual spaces with artificial configurations of information. These images are distinct from image-traces because of their ability to emulate the human brain in the creation of models of the world, resulting from abstraction processes that do not require the previous participation of a body. These images dispense with the mediation of bodily experience, with human beings' positioning and consequent point of view before phenomenal reality. In this way, the sensible makes room for the intelligible, for the materialisation of the theory underlying the synthesis of electro-numerical images, whose referent coincides with the brain-machine that generated them. Therefore, these computational representations no longer correspond to images of the physis. A second technological nature is added to the physis, extending it and increasing the complexity of space-time. Different places and times get mixed up and, by becoming virtual, are multiplied in a process of deterritorialization and desynchronization through which mankind places itself before and beyond the space-time of the world.

Indeed, this "heterogenesis of the human" is not only specific to technological virtualisation; it is a continuation of the hominization process (cf. LÈVY, 1997, p. 63) through which mankind has since always emancipated itself from the biological limitations imposed by nature. The virtualisation carried out by images tout court has always allowed mankind to create spaces in which to live and travel, protected against the "irrationality" and unpredictability of the world.

\footnotetext{
${ }^{8}$ As Coquet $(2008$, p. 2) states, "[t]he assumption of the phenomenon, of the presentation of the natural being [...] makes the analyst distinguish between the perceptual and the conceptual instances. The first, somatic, driven by passion [...], establishes its relationship with the world: it is the moment of apprehending the sensible world. The second, judgmental, which makes the judgment known, describes the actual experience: it is the moment of re-apprehending. The division between the two moments—apprehension and re-apprehension-can be extended to all forms of experience." (my translation)
} 
However, while since the Lumière views the image-trace gives life to a heterotopic place where each frame corresponds to a certain point of view-favouring a common visual experience shared by author and spectator, a perceptual adventure around the "world that becomes an image"-, the electro-numerical image generates the u-topian ${ }^{9}$ and solipsistic space of the "imagination that becomes the world" (DANEY, 1993, p. 151) - a world that exists but cannot be located, on whose surface images devoid of experience (since no human gaze claims their paternity) come one after the next.

\section{REFERENCES}

ARENDT, Hannah. The human condition. Chicago: The University Chicago Press, 1958. Available in: 〈http://goo.gl/tIbRiQ>. Access in: 01 Sep. 2016.

BENJAMIN, Walter. The storyteller. Observations on the works of Nikolai Leskov. In: EILAND, Howard; JENNINGS, Michael W. (Ed.). Walter Benjamin: selected writings. Vol. III - 1935-1936. Cambridge/London: The Belknap Press of Harvard University Press, 2002, p. 143-166.

BENJAMIN, Walter. Paris, the capital of the nineteenth century. Daguerre, or the panoramas. In: BENJAMIN, Walter. The arcade project. Translators of Howard Eiland and Kevin McLaughlin. Cambridge/London: The Belknap Press of Harvard University Press, 2003, p. 05-06. Available in: 〈http://goo.gl/4OEerZ〉. Access in: 01 Sep. 2016.

BERTETTO, Paolo. Lo specchio e il simulacro. Il cinema nel mondo diventato favola. Milan: Bompiani, 2008.

BRUNO, Giuliana. Atlante delle emozioni. In viaggio tra arte, architettura e cinema. Milan: Bruno Mondadori Editori, 2006.

CAPUCCI, Pier Luigi. Realtà del virtuale. Rappresentazioni tecnologiche, comunicazione, arte. Bologne: Clueb, 1993.

CASETTI, Francesco. L'occhio del novecento. Cinema, esperienza, modernità. Milan: Bompiani, 2005.

COQUET, Jean-Claude. Le istanze enuncianti. Fenomenologia e semiotica. Milan: Bruno Mondadori Editori, 2008.

DANEY, Serge. Ciné Journal 1981-1986. Paris: Cahiers du Cinéma, 1986.

DANEY, Serge. L'exercice a été profitable, Monsieur. Paris: P.O.L., 1993.

DANEY, Serge. Persévérance. Paris: P.O.L., 1994.

DE VECCHI, Cristina. La rappresentazione del paesaggio. Funzione documentaria e riproducibilità tecnica. Milan: Cuem, 2000.

FARINELLI, Franco. La crisi della ragione cartografica. Turin: Einaudi, 2009.

\footnotetext{
${ }^{9}$ The use of the hyphen in the word "utopian" intends to emphasise the double meaning of the term as used by Thomas More: both an "ideal land" and a "no-land", i.e. a space without physicality.
} 
LÉVY, Pierre. Il virtuale. Milan: Raffaello Cortina Editore, 1997.

MERLEAU-PONTY, Maurice. L'CEil et l'Esprit. Paris: Éditions Gallimard, 1964a.

MERLEAU-PONTY, Maurice. Le visible et l'invisible. Paris: Éditions Gallimard, 1964b.

MERLEAU-PONTY, Maurice. Sens et non-sens. Paris: Éditions Gallimard, 1996.

PARENTE, André. O virtual e o hipertextual. Rio de Janeiro: Pazulin, 1999. Available in: <http://goo.gl/emdxWn>. Access in: 01 Sep. 2016.

PARENTE, André. Imagens que a razão ignora: a imagem de síntese e a rede como novas dimensões comunicacionais. Galáxia: Revista Transdisciplinar de Comunicação, Semiótica, Cultura, São Paulo, SP, n. 04, p. 113-123. 2002. Available in: 〈http://goo.gl/6YpO3k〉. Access in: 01 Sep. 2016. ISSN 1982-2553.

SCHEFER, Jean Louis. L'homme ordinaire du cinéma. Paris: Éditions Gallimard, 1980.

SLOTERDIJK, Peter. Il mondo dentro il capitale. Translator Rodeschini, Silvia. Rome: Maltemi, 2006.

VIRILIO, Paul. Esthétique de la disparition. Paris: Édition Galilée, 1989.

VIRILIO, Paul. L'art à perte de vue. Paris: Éditions Galilée, 2005.

FRANCESCO GIARRUSSO

Doutor em Comunicação e Linguagens Universidade de Nova Lisboa, UNL, Portugal.

E-mail: giarrusso.f@gmail.com

Recebido em: 01/09/2016 Aceito para publicação em: 20/09/2016.

\section{Como citar este documento:}

GIARRUSSO, Francesco. Images of world: from the images-trace to the electro-numerical space. ETD Educação Temática Digital, Campinas, SP, v. 18, n. 4, p. 820-834, nov. 2016. ISSN 1676-2592. Disponível em: 〈http://periodicos.sbu.unicamp.br/ojs/index.php/etd/article/view/8646423 >. Acesso em: 16 nov. 2016. doi:http://dx.doi.org/10.20396/etd.v18i4.8646423. 